\title{
Capitalism and democracy in the twenty-first century: does it still take two to tango?
}

\author{
Matteo Marenco \\ Scuola Normale Superiore, Faculty of Political and Social Sciences, Piazza Degli Strozzi, Florence 50123, Italy \\ Corresponding author. Email: matteo.marenco@sns.it
}

(Received 3 May 2021; revised 19 May 2021; accepted 20 May 2021; first published online 21 June 2021)

\begin{abstract}
This article reviews three books that offer thought-provoking insights on a central political science question, namely the relationship between capitalism and democracy in the twenty-first century. First, 'Democracy and Prosperity' by Iversen and Soskice posits a symbiotic relationship between capitalism and democracy. Advanced capital thrives on nationally rooted institutions, hence it needs democratic politics. A majority of voters ask for pro-advanced-capital reforms, hence democratic politics needs advanced capital. Second, 'Capitalism, Alone' by Milanovic depicts a troubled coexistence between capitalism and democracy. The former's tendency to concentrate economic and political power in the hands of the few is the main reason why democratic politics is under pressure. Third, 'The Age of Surveillance Capitalism' by Zuboff suggests a negative relationship between digital capitalism and democracy. Surveillance capitalism increasingly acts as a control means of individuals' behaviour, which undermines democracy at its roots. The last section brings the three contributions together. It maintains that a mutually beneficial coexistence between capitalism and democracy currently faces both internal (from within) and external (from without) challenges. In line with Milanovic and Zuboff, it argues that the concentration of economic and political power in the hands of the few is the most apparent from-within challenge. Drawing on Milanovic, it contends that rise of China as a global power combining capitalism with nondemocracy challenges the relationship between capitalism and democracy from without. Finally, it contends that the environmental question and the pandemic represent two windows of opportunity for democracy to recover lost ground and re-establish a more balanced relationship with capitalism.
\end{abstract}

Key words: Capitalism; Democracy; Authoritarianism; Inequality; Digitalization

\section{Introduction}

The coexistence of free markets and democratic politics has been a long-standing conundrum for political scientists. Since the end of the post-war Keynesian compromise, discussions on the matter have intensified as the balance of power between states and globalizing capital swung in the latter's direction. The neoliberal version of capitalism that emerged from such a shift has so far proven remarkably resilient even in the face of the 2007 self-inflicted financial crisis (Crouch, 2011). About 15 years ahead of the crisis and amid a pandemic acting as a 'great accelerator' of existing tensions, recently emerged challenges exacerbate more long-standing ones. Digitalization is taking place in a context of sluggish productivity and increasing debt, endemic corruption, and declining electoral turnouts, mounting income inequalities, and strengthening of populism. Taken together, these issues urgently speak to the present and future relationship between capitalism and democracy. How does such a relationship look like nowadays? Do we observe mutually beneficial mechanisms that reinforce this historically challenging coexistence?

(C) The Author(s), 2021. Published by Cambridge University Press on behalf of the Società Italiana di Scienza Politica. This is an Open Access article, distributed under the terms of the Creative Commons Attribution licence (http://creativecommons.org/licenses/by/4.0/), which permits unrestricted re-use, distribution, and reproduction in any medium, provided the original work is properly cited. 
Table 1. List of books reviewed

\begin{tabular}{|c|c|c|c|c|}
\hline Author & Title & Publisher & Year & $\begin{array}{l}\text { Capitalism-democracy } \\
\text { relationship }\end{array}$ \\
\hline $\begin{array}{l}\text { Torben Iversen and } \\
\text { David Soskice }\end{array}$ & $\begin{array}{l}\text { Democracy and Prosperity: Reinventing } \\
\text { Capitalism Through a Turbulent Century }\end{array}$ & $\begin{array}{l}\text { Princeton } \\
\text { University } \\
\text { Press }\end{array}$ & 2019 & Positive \\
\hline Branko Milanovic & $\begin{array}{l}\text { Capitalism, alone: The Future of the System that } \\
\text { Rules the World }\end{array}$ & $\begin{array}{l}\text { Harvard } \\
\text { University } \\
\text { Press }\end{array}$ & 2019 & Troubled \\
\hline Shoshana Zuboff & $\begin{array}{l}\text { The Age of Surveillance Capitalism: The Fight } \\
\text { for a Human Future at the Frontier of Power }\end{array}$ & Profile Books & 2019 & Negative \\
\hline
\end{tabular}

Or do we see, by contrast, detrimental movements that can cause unprecedented ruptures in it? This article tackles these questions by reviewing three recent books that offer thought-provoking insights on capitalism and democracy in the 21st century (see Table 1). It does not provide thorough reviews but reflects on how each book relates to the aforementioned questions. Throughout the paper, capitalism is intended as 'neoliberal', that is, the historically specific form of wealth creation, extraction, and accumulation that gained traction in the late 1970s and emphasizes the centrality of market mechanisms as opposed to market-correcting State regulation (Harvey, 2005). To reflect upon the relationship between capitalism and democracy, we should go beyond procedural definitions of democracy that focus on elections. We should include in our definition elements that ensure the practical 'meaningfulness' of elections (Merkel, 2004). Following Merkel (2014), therefore, democracy is understood as 'embedded', that is consisting of five partial regimes: (i) democratic elections, (ii) political participation, (iii) civic rights, (iv) institutional protection of power separation, (v) democratically elected representatives that effectively exercise their power both de jure and de facto.

The remainder of the paper is organized as follows. The section 'Knowledge-based capitalism and democracy: a virtuous circle?' focuses on 'Democracy and Prosperity'. The third section 'Equality among unequals: how is democracy compatible with rising income inequality?' concentrates on 'Capitalism, alone'. The section after on 'Digital capitalism and democracy: an impossible coexistence?' discusses 'The Age of Surveillance Capitalism'. The final section brings the three contributions together. It argues that a mutually beneficial coexistence between capitalism and democracy faces both internal (from within) and external (from without) challenges. In line with Milanovic and Zuboff, it maintains that the concentration of economic and political power in the hands of the few is the most apparent from-within challenge. Drawing on Milanovic, it contends that rise of China as a global power whose model combine capitalism with non-democracy puts from-without pressure on the relationship between capitalism and democracy. Finally, it contends that the environmental question and the pandemic represent two windows of opportunity for democracy to recover lost ground and re-establish a more balanced relationship with capitalism.

\section{Knowledge-based capitalism and democracy: a virtuous circle?}

Democracy and Prosperity theorizes a positive relationship between the current form of capitalism, which the authors call advanced, and democracy. The adjective advanced refers to knowledge-intensive capital and production. Iversen and Soskice's argument is predicated upon three tenets. First, governments are crucial in and for advanced capitalism. Contrary to what is often argued (see for instance, Streeck, 2009; Piketty, 2014), Iversen and Soskice maintain that globalization has reinforced democratic politics because the latter is fundamental to ensure that firms operate in a competitive environment where 'rules of the game' are clear and stable enough to avoid damaging beggar-thy-neighbour strategies. Second, democracies have incentives in regulating advanced capitalism because the electoral premium for parties that show 
outstanding economic competencies is particularly high. Third, advanced capital, which is highly dependent on knowledge, is geographically entrenched rather than selfishly running after low labour costs across borders. Skill formation systems, which are national creatures, are the primary reason why capital is relatively immobile.

According to Democracy and Prosperity, the interests of labour and capital do not collide in advanced capitalism. Rather, the skilled workforce of the knowledge-intensive sectors and the 'aspirational voters' who aim to become part of such a workforce are interested in furthering advanced capitalism and will cast their ballots accordingly. This is how labour and capital interests go hand in hand. But what about the lower-end of the skill spectrum, which has no evident reasons to support skill-intensive capitalism? Iversen and Soskice concede that advanced capitalism comes with a new skill-centred cleavage that offers a breeding ground for the emergence of populism. The latter, nonetheless, threatens neither advanced capital nor democracy. This has two explanations. First, 'part of the populist reaction is in fact a call to be included in the wealth stream of the new economy' (p. 218). Second, policies that are expressly against the knowledge economy are unlikely to achieve enduring electoral success simply because they are of no convenience to the middle classes.

What does Democracy and Prosperity tell us about the contemporary relationship between capitalism and democracy? First, Iversen and Soskice's book is compelling in re-stating the centrality of national skill-formation systems in knowledge-intensive capitalism (Hall and Soskice, 2001). As also Mazzucato (2013) shows, despite the free markets mantra, the nation-state is a key reservoir of knowledge in today's economy. It would then be simply wrong to argue that advanced capital could retain its profitability without democratic institutions. However, a more problematic question pertains to the other side of the argument, which states that democratically elected governments have undertaken the 'political construction' of knowledge economies in response to electoral demands. Unquestionably, policy decisions have been decisive to the emergence and reinforcement of advanced capital. But to contend that they have been taken in the first place because of electoral demands means to mistakenly assume politicians to be free from any business power, which overlooks a vast strand of political science literature devoted to such a concept (Lindblom, 1982; Vogel, 1987; Hacker and Pierson, 2010; Culpepper, 2011). Building on this scholarship, a reversed interpretation of the argument proves more convincing. That is: governments did not enact pro-knowledge-economy reforms because voters demanded them. Rather, voters wanted them - and governments adopted them - because knowledge-intensive companies increasingly became the privileged loci for value-added creation, which significantly increased their political leverage. For skilled-enough voters, this meant job opportunities. For governments, this resulted in enhanced competitiveness on the global stage. Thus, democratic politics did not 'construct' the knowledge economy because a consistent majority of voters pushed for it. Rather, advanced capital became so indispensable to national economies that governments found themselves forced to accommodate it to navigate the waters of globalization.

The conception of populism enshrined in Democracy and Prosperity speaks to the relationship between capitalism and democracy too. As mentioned above, Iversen and Soskice conceive of populism as no serious threat to the symbiosis between capitalism and democracy. While this may well be true, it does not say much about the strength of such a symbiosis. Instead, what is telling in this regard is the emergence of populism itself. The mere fact that 'anti-system politics' (Hopkin, 2020) has grown to such an extent shows that while advanced capital was advancing, increasing parts of the electorate were being left behind and felt the need to re-asserting their citizenship rights. This suggests a truncated-symbiosis scenario where advanced capital primarily benefits the knowledge-intensive segment of the workforce at the expense of the others. No doubt, as Iversen and Soskice maintain, skill provision systems are effective tools for cushioning such harms. Yet only a minority of training systems are well-equipped to thrive in knowledgeintensive capitalism. In countries where skill formation is inadequate, then a substantial portion of voters will oppose the knowledge economy as a system that excludes them. 'Aspirational voters' 
matter as long as they can have reasonable expectations of upward mobility. If they cannot, they seek an alternative that promotes - at least in discourse - their interests. Hence, 'anti-system politics' (Hopkin, 2020).

\section{Equality among unequals: how is democracy compatible with rising income inequality?}

'Anti-system politics' (Hopkin, 2020) thrives on the existence of multiple malaises - what Streeck (2016) calls 'multi-morbidity' - that severely undermine the capitalism-democracy symbiosis depicted in Democracy and Prosperity. Among them, growing income inequality between a small percentage of super-rich and the rest of the population has been at the forefront of heated discussions. While it comes as no surprise that capitalism generates inequality, the last four decades have shown the evident incapacity of democratic institutions to mitigate the rise of income inequality. Capitalism, alone engages with this discussion by concentrating on the implications of 'the global victory of capitalism' (p. 176) in terms of income inequality and class structure. It identifies two variants of capitalism that have come into being over the last four decades, i.e., 'Liberal meritocratic capitalism' and 'Political capitalism'. The former, epitomized by the US, distributes goods and services by rewarding 'talent' (meritocratic) and, at the same time, seeking to reduce the intergenerational transmission of disadvantages (liberal). In principle, it is on good terms with democracy. Four inequality-fuelling elements, however, are likely to hinder such a fruitful relationship. First, the share of capital income (relative to labour) in the total product is on the rise. Second, capitalrich individuals are more and more frequently also labour-abundant, which means that they possess 'slices of the cake' that were previously eaten by wage workers who earned virtually no capital income. Third, better-off individuals increasingly marry each other. This relates to a fourth element, which is a high correlation of income between parents and children. Political capitalism, of which China is the most prominent instance, is characterized by the combination of (i) highly efficient bureaucratic machine (ii) absence of the rule of law (iii) marked autonomy of the State. The fact that a scant application of the rule of law undermines administrative efficiency makes political capitalism 'always in precarious equilibrium' (p. 95). Political capitalism presents high level of inequality as well - especially in terms of mounting share of capital income and its concentration in the hands of the rich. Contrary to Iversen and Soskice, Milanovic argues that globalization has rendered capital and labour - in both systems - fundamentally mobile. This has fuelled inequality, led to greater commodification and fostered atomization thereby undermining 'the human relations and trust that are needed for the market economy to function smoothly' (p. 192).

Capitalism, alone proves both incomplete and enlightening with regard to the relationship between capitalism and democracy. On the one hand, the author notes that the inequalitycreating character of neoliberal capitalism puts pressure on democratic politics. Yet he does not elaborate on the concrete consequences of such problems for democratic institutions, which makes it hard to understand how inequality is actually threatening democracy. Furthermore, Milanovic puts forward policy measures - e.g., tax advantages for the middle class, increased investments in public schooling, solely publicly funded electoral campaigns that might pave the way for a more egalitarian version liberal meritocratic capitalism. The question of how these policies, which would overtly challenge the status quo, can be adopted in the present scenario remains nonetheless obscure. This somewhat relegates Milanovic's proposals to interesting but prescriptive recommendations. On the other hand, the analysis of political capitalism spotlights a crucial element largely disregarded in the other books analysed here: to understand the present and future relationship between democracy and capitalism, it is (also) necessary to pay due attention to how non-democratic regimes connect with capitalism. China is the example par excellence. In a period of extraordinary economic growth and mounting geopolitical strength, China is likely and arguably willing to benefit from the weakening incontestability of the association between democracy and capitalism by proposing its own model as more effective than low-growth Western democracies. Take 'The Belt and Road Initiative', the China-sponsored 
investment initiative to develop a vast array of transport networks to foster regional integration and cross-border trade from East Asia to Africa and Europe (Chen et al., 2021); or the Chinese strategy in Africa entailing massive direct infrastructural investments (Ching-Kwan, 2017). Such actions have enhanced China's credibility as a global player and thus improved the legitimacy of political capitalism in the international arena.

\section{Digital capitalism and democracy: an impossible coexistence?}

Digitalization, intended as the increasing diffusion of digital technologies in our economic, political, and social experiences, is arguably the most far-reaching transformation our societies are undergoing. In The Age of Surveillance Capitalism, Zuboff traces the origins and consolidation of a new type of capitalist mode of production associated with the rise of digital tech giants such as Google and Facebook. What she terms 'surveillance capitalism' has its roots in the digital hyper-optimism that characterized the early 2000s and conceived of the World Wide Web as a dreamlike non-place where freedom would reach its purest form. According to Zuboff, however, initial democratizing expectations were soon replaced by an unprecedented form of capitalism, namely surveillance capitalism, that relies on surveillance to transform investments into profit. The neoliberal ethos, gradually become dominant since the mid-1970s, offered this new mode of production a functional ideational toolkit for its emergence and expansion. Surveillance capitalism, of which Google has been the master, comes with its own 'laws of motion', Zuboff notes. Behavioural surplus, namely the potential profit extractable from billions of users' behavioural data, is the backbone of the system. The 'means of behavioural modification', as Zuboff calls the digital infrastructure that allows for behavioural data extraction, function through increasing returns mechanisms, that is: the more data they consume the more accurate their predictions become, and the higher the profits they generate. The predictive capacity of digital giants is now so pervasive that people's choices have become themselves the result of data-driven predictions. Surveillance capitalists, then, do not simply predict human behaviour; because they command the 'division of learning in society', they in fact shape human behaviour by predicting it. This is a new form of power that Zuboff terms instrumentarianism.

Zuboff compellingly maintains that these developments are fundamentally undermining Western democracies. Challenges to democratic politics, however, are treated as given and largely left unspecified. For instance, how does instrumentarianism affect electoral behaviour and party competition? Such is a crucial question that Zuboff does not address. An interesting, if partial, answer to such queries comes from the concept of 'platform power' developed Culpepper and Thelen (2020). 'Unlike previous generations of large companies on which the broader economy came to depend, such as railways or utility companies, today's largest platforms enjoy a tight, even intimate, connection to their users' (Culpepper and Thelen, 2020, p. 290). Platform power is the strength of such a connection. The latter begs the question of how the alliance between platforms and consumers feeds back into the democratic process when citizens - many of whom are also consumers - are called to cast their ballot on a measure that goes against platforms. The recent developments in the politics of gig economy regulation in California well illustrate these dynamics. In September 2019, the so-called AB5 legislation restricted the possibility for gig platforms to work with independent contractors. Under AB5, workers are classified as self-employed only if the platform is able to demonstrate, through a specific test, their autonomy. Otherwise, they are classified as employees. With the aim of sidestepping AB5, California Proposition 22 on 'App-based drivers as contractors and Labour Policies Initiative' (Prop. 22) was promoted and supported with more than $\$ 200$ million by platforms Uber, Lyft, Doordash, and Instacart. Prop. 22 was an initiated state statute $^{1}$ proposing that AB5 legislation cannot be used to

$1 \mathrm{An}$ initiated state statute is a law that a State might adopt following a petition signed by a given number of registered voters. 
determine the job classification of platform workers. In November 2020, Californians were asked to either support Prop. 22 or oppose it. About $60 \%$ of voters approved Prop. 22, which marked an important victory for platforms. The ballot on Prop. 22 is a vivid example of platform power, that is of how platforms can mobilize substantial financial resources to trigger their alliance with consumers for political ends.

\section{Conclusion}

These three recent books show the saliency of and contestation around the relationship between capitalism and democracy. Overall, Capitalism, alone and The Age of Surveillance Capitalism prove particularly able in throwing light on the tense relationship between neoliberal capitalism and democratic politics. By contrast, Democracy and Prosperity does not capture such tensions because it overvalues, in my view, the electoral implications of advanced capitalism. The main takeaway from these books, I argue, is that a mutually beneficial relationship between 'neoliberal' capitalism and democratic politics is currently hindered both from within and from without. From-within challenges are endogenously generated tensions. Rising income inequality and the widespread application of digital technologies are two of the most challenging trends from within. Previous literature has shown how economic inequality undermines both political participation and representation by affecting electoral turnouts of middle and lower classes (Hacker and Pierson, 2010; Bonica et al., 2013; Merkel, 2014). As for the impact of digital capitalism on democracy, empirical evidence is still less established. Yet the global role of social networks as privately owned public opinion makers and the disproportionate power of companies like Google to influence people's behavioural patterns constitute good reasons to contend that digital capitalism puts pressure on democratic politics.

From-without challenges develop 'outside' the relationship between capitalism and democracy, but reverberate on it. The relatively recent ascent of China as a global economic and political power is a major challenge from without. China offers a credible - though contestable alternative that associates capitalism with a non-democratic form of government. The success of 'political capitalism's further weakens the association between capitalism and democracy, already battered by the market-first credo that has gained traction over the last four decades'.

In light of such profound challenges, how can democratic politics recover lost ground? The three books reviewed here do not provide an accurate answer to this query. I contend that there at least two windows of opportunity that democratic politics could take advantage of to re-establish a more balanced relationship with capitalism. The first window has to do with the increasing public awareness on the environmental footprint of human economic activities. In a world where it has become clear that ever-expanding commodification is both undesirable and unrealistic, the environmental question can potentially be politicized across the political spectrum. This may foster citizens' participation and representation, thereby reinforcing the role of democratic politics in shaping the rules of the game. A second window of opportunity is the pandemic, which is vividly showing the extent to which marked socioeconomic inequalities have long remained politically unheard despite permeating our societies. The breakdown of collective agency brought about by neoliberalism is part of the explanation why such inequalities have found little political representation thus far (Streeck, 2016), and constitutes an example of how the current form of capitalism has trumped democratic politics. That said, the pandemic will open up room for reconsidering the relationship between capitalism and democracy. In such a space, democratic politics can find ways to address unanswered citizens' instances and restore a more balanced, possibly mutually beneficial relationship with the market. Future research should look into whether and how these two windows will be opened, by whom, and with what political and policy outcomes.

\section{References}

Bonica A, McCarty N, Poole KT and Rosenthal H (2013) Why hasn't democracy slowed rising inequality? Journal of Economic Perspectives 27, 103-124. 
Chen D, Song D and Yang Z (2021) A review of the literature on the belt and road initiative with factors influencing the transport and logistics. Maritime Policy \& Management 7, 265-271.

Ching-Kwan L (2017) The Specter of Global China: Politics, Labour, and Foreign Investments in Africa. Chicago and London: University of Chicago Press.

Crouch C (2011) The Strange Non-Death of Neoliberalism. Cambridge: Polity Press.

Culpepper P (2011) Quiet Politics and Business Power. New York: Cambridge University Press.

Culpepper P and Thelen K (2020) Are we all Amazon primed? Consumers and the politics of platform power. Comparative Political Studies 53, 288-318.

Hacker JS and Pierson P (2010) Winner-Take-All-Politics: How Washington Made the Rich Richer-And Turned its Back on the Middle Class. New York: Simon \& Schuster.

Hall P and Soskice D (2001) Varieties of Capitalism: The Institutional Foundations of Comparative Advantage. Oxford: Oxford University Press.

Harvey D (2005) A Brief History of Neoliberalism. Oxford: Oxford University Press.

Hopkin J (2020) Anti-System Politics: The Crisis of Market Liberalism in Rich Democracies. Oxford: Oxford University Press. Lindblom C (1982) The market as prison. The Journal of Politics 44, 324-336.

Mazzucato M (2013) The Entrepreneurial State: Debunking Public vs. Private Sector Myths. London: Anthem Press.

Merkel W (2004) Embedded and defective democracies. Democratization 11, 33-58.

Merkel W (2014) Is capitalism compatible with democracy? Zeitschrift für vergleichende politikwissenschaft 8, 109-128.

Piketty T (2014) Capital in the Twenty-First Century. Cambridge: Belknap Press of Harvard University Press.

Streeck W (2009) Re-Forming Capitalism. Oxford: Oxford University Press.

Streeck W (2016) How Will Capitalism End? Essays on a Failing System. New York: Verso Books.

Vogel D (1987) Political science and the study of corporate power: a dissent from the new conventional wisdom. British Journal of Political Science 17, 385-408.

Cite this article: Marenco M (2022). Capitalism and democracy in the twenty-first century: does it still take two to tango? Italian Political Science Review/Rivista Italiana di Scienza Politica 52, 134-140. https://doi.org/10.1017/ipo.2021.23 